Aurelia Journal
(Authentic Research of Global Fisheries Application Journal)
p-ISSN: 0000-0000
e-mail: aurelia.journal@gmail.com

\title{
PENGARUH PERBEDAAAN KONSENTRASI GARAM TERHADAP KOMPOSISI PROKSIMAT IKAN BIANG (llisha elongata) ASIN KERING
}

\section{THE EFFECT OF DIFFERENT CONCENTRATION OF SALT TO THE PROXIMATE COMPOSITION OF DRIED SALTED BIANG FISH (Ilisha elongata)}

\author{
Aulia Azka1*, Putri Wening Ratrinia1, Nirmala Efri Hasibuan1, Kurnia Sada Harahap1 \\ ${ }_{1}^{1}$ Politeknik Kelautan dan Perikanan Dumai, Dumai, Indonesia \\ *Korespondensi: azkaa8586@gmail.com (A Azka) \\ Diterima 22 Juli 2019 - Disetujui 19 September 2019
}

\begin{abstract}
ABSTRAK . Ikan biang (Ilisha elongata) memiliki nilai konsumsi yang tinggi di Provinsi Riau. Di Indonesia ikan biang biasanya diolah menjadi ikan asin agar tahan lama. Metode penggaraman yang dilakukan adalah penggaraman kering dengan kadar garam 5\%, 10\% dan 15\% (b/b). Tujuan dari penelitian ini adalah menentukan komposisi proksimat ikan biang asin kering dengan perbedaan konsentrasi garam.Pengujian dilakukan di Politeknik Kelautan dan Perikanan Dumai, Laboratorium karakteristik bahan baku hasil perikanan THP IPB dan Laboratorium Kimia Terpadu IPB. Hasil penelitian menunjukkan kadar air ikan biang asin kering berkisar $14.09 \%$ - 18,71\%. kadar abu berkisar $22.20 \%$ - $24.02 \%$, kadar protein sebesar $46.68 \%$ $49.08 \%$, lemak sebesar $4.52 \%-5.77 \%$, dan karbohidrat $6.07 \%-9.55 \%$. Hasil penelitian memberikan informasi bahwa perbedaan konsentrasi garam berpengaruh terhadap komposisi proksimat ikan biang asin kering.
\end{abstract}

KATA KUNCI: Ikan biang; ikan asin kering; proksimat

ABSTRACT. Biang fish (llisha elongata) has a high consumption value in Riau Province. In Indonesia biang fish usually processed into salted fish to make it last longer. The salting method used is dry salting with salinity of $5 \%, 10 \%$ and $15 \%(\mathrm{w} / \mathrm{w})$. The purpose this study is to determine water, ash, protein, fat, and carbohydrate content Testing was carried out at the Politeknik Kelautan dan Perikanan Dumai, Laboratory characteristics of raw materials resulting from fisheries of THP IPB and IPB Integrated Chemistry Laboratory. The results showed that the water content ranged from $14.09 \%-18.71 \%$. ash content ranges from $22.20 \%-24.02 \%$, protein content of $46.68 \%-49.08 \%$, fat is $4.52 \%-5.77 \%$ and carbohydrate is $6.07 \%$ - $9.55 \%$. The results of the study provide information that differences in salt concentration affect the proximate composition of dried salted Biang fish.

\section{KEYWORDS: Llisha elongata; dried salted fsh; proximat}

\section{Pendahuluan}

Provinsi Riau merupakan salah satu provinsi yang memiliki potensi perikanan yang melimpah di Indonesia. Menurut BPS Provinsi Riau (2015), potensi produksi perikanan di Riau yaitu sebesar 105.296,3 ton. Jenis ikan yang memiliki nilai konsumsi yang tinggi di Provinsi Riau adalah ikan biang (Ilisha elongata). Produksi biang pada tahun 2015 menurut BPS (2015) adalah sebesar 2091,7 ton.

Ikan biang memiliki nama lokal Gemprang, Pernate, dan Kemprit. Ikan biang (llisha elongata) hidupnya bergerombol, jumlahnya tidak banyak, panjang tubuhnya sekitar $30-60 \mathrm{~cm}$ (Novicov et al., 2002). Ikan biang terdapat di wilayah Indo-Pasific, Samudra Hindia, Laut jawa, dan laut Cina Selatan. Di Indonesia wilayah penyebarannya di Laut jawa, Sumatera, Kalimantan, Sulawesi Selatan, dan Arafuru. Ikan biang merupakan salah satu ikan komersil penting di Jepang dan Cina (Zhang \& Takita, 2007). Di Indonesia ikan biang diolah menjadi ikan asin dan ikan peda. 
Pengasinan merupakan suatu cara pengolahan tradisional ikan dengan hasil produk berupa ikan asin. Pengasinan bertujuan agar ikan lebih awet atau tahan lama. Pengasinan adalah suatu proses pengolahan ikan dengan cara memberikan garam sehingga mempunyai kandungan garam sangat tinggi ( $\mathrm{NaCl}$ yang jenuh pada fase masih mengandung air) yang kemudian dikeringkan. Pengolahan ikan asin kering oleh masyarakat masih secara tradisional sehingga penggunaan konsentrasi garam berbeda berdasarkan individu. Tingkat penerimaan atau kesukaan konsumen terhadap ikan biang asin kering ini perlu diperhatikan, karena penerimaan konsumen menjadi salah satu faktor yang berpengaruh pada konsumsi suatu bahan pangan. Komposisi proksimat yakni kadar air merupakan salah satu persyartan mutu ikan asin kering. Menurut SNI 2721.1:2009, persyaratan maksimal kadar air pada ikan asin kering adalah 40\%. Penelitian terkait pengaruh konsentrasi garam terhadap komposisi proksimat mutu ikan biang asin kering belum pernah dilakukan. Sehingga penelitian ini bertujuan untuk mengetahui komposisi proksimat ikan biang asin kering.

\section{Bahan dan Metode}

\subsection{Bahan dan Alat}

Bahan utama yang digunakan adalah ikan biang (Ilisha elongata) yang diperoleh dari Dumai, Provinsi Riau. Bahan kimia yang digunakan yaitu akuades, kjeltab jenis selenium, larutan $\mathrm{H}_{2} \mathrm{SO}_{4}$ pekat, $\mathrm{NaOH}, \mathrm{H}_{3} \mathrm{BO}_{3}$, larutan $\mathrm{HCl} 0.1 \mathrm{~N}, \mathrm{HCl} 6 \mathrm{~N}_{3}, \mathrm{H}_{3} \mathrm{BO}_{4} 2 \%$, buffer natrium karbonat, ethanol-ascorbic acid 0.1 $\%, \mathrm{KOH}$, larutan heksana, kapas bebas lemak, alumina aktif, natrium sulfat anhidrat $\left(\mathrm{Na}_{2} \mathrm{SO}_{4}\right)$ serbuk, alumina aktif, $\mathrm{SnCl}$, $\mathrm{HNO} 3$ pekat, $\mathrm{MgNO}$, dan lantannum $5 \%$.

Alat yang digunakan antara lain baskom, tampah, plastik box, nampan plastik, talenan, pisau, titimbangan analitik Sartonius tipe TE15025, cawan porselen, oven Yamato tipe DV-41, desikator (analisis kadar air); tabung reaksi, labu Erlenmeyer, tabung Sokhlet, pemanas Sibata tipe SB-6 (analisis kadar lemak); tabung Kjeldahl, destilator, buret (analisis kadar protein); tanur Yamato tipe FM 38 dan desikator (analisis kadar abu).

\subsection{Metode Penelitian}

\section{Preparasi Bahan Baku}

Penelitian ini diawali dengan pengujian organoleptik berdasarkan score sheet ikan segar. Kemudian ikan disiangi, dibuang isi perut, insang, dan sisik, kemudian tubuh ikan dibelah menjadi dua bagian (butterfly fillet) .Ikan yang telah disiangi dicuci dan ditiriskan. Setelah ikan ditiriskan, ikan ditimbang untuk mengetahui bobot ikan dan dapat menentukan konsentrasi garam yang akan ditambahkan.

\section{Pembuatan Ikan Asin}

Ikan ditambahkan garam dengan garam A: 5\%, B: 10\%, dan C: 15\% (b/b). Metode penggaraman yang digunakan adalah penggaraman kering. Ikan yang telah dilemuri garam dalam wadah secara merata kemudian dibiarkan selama 24 jam dibawah sinar matahari.

\subsection{Analisis Proksimat}

Analisis proksimat yang dilakukan mengacu pada metode AOAC (2005). Analisis proksimat yang dilakukan meliputi analisis kadar air, abu, protein, dan lemak. Analisis kadar karbohidrat menggunakan by different. 


\section{Hasil dan Bahasan}

\subsection{Kadar Air}

Air merupakan komponen yang penting dalam bahan makanan, air dapat memberikan pengaruh pada penampakan, tekstur dan cita rasa. Bahkan di dalam makanan kering sekalipun, terkandung air dalam jumlah tertentu.Kandungan air dalam bahan makanan ikut menentukan daya terima, kesegaran serta daya simpan bahan tersebut (Winarno, 2008). Kadar air ikan biang asin kering berkisar antara $14,09 \%-18,71 \%$. Kadar air ikan asin kering ditentukan oleh kadar kering atau tidaknya ikan olahan, lamanya proses pengeringan yang kesemuanya biasanya berhubungan dengan daya awet dari produk olahan (Tuyu et al., 2014). Selain itu, hal yang juga mempengaruhi kadar air adalah jumlah konsentrasi garam yang ditambahkan ke ikan. Adanya perbedaan konsentrasi (driving force) yang cukup besar antara konsentrasi larutan garam dengan konsentrasi cairan di dalam daging ikan. Semakin besar perbedaan konsentrasi, driving force awal dari proses penggaraman semakin besar, sehingga difusi solut ke dalam daging ikan semakin besar (Medina-Vivano et al., 2002). Ningrum et al., (2019) menyatakan bahwa kadar air ikan asin cenderung turun dengan meningkatnya lama penggaraman. Semakin lama daging ikan direndam dalam larutan garam maka air yang keluar dari bahan semakin banyak. Berdasarkan Gambar 1, dapat dilihat bahwa seluruh produk sudah memenuhi standar kadar air yang disyaratkan oleh Standar Nasional Indonesia (SNI) untuk mutu ikan asin kering. Kadar air untuk produk ikan asin yang ditetapkan dalam SNI (2009) adalah 40\%.

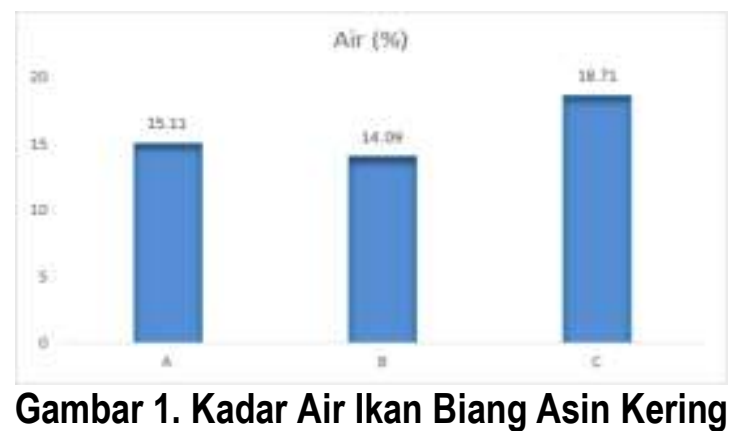

\subsection{Kadar Abu}

Abu merupakan zat organik sisa hasil pembakaran suatu bahan organik. Bahan makanan terdiri dari $96 \%$ bahan organik dan air. Sisanya terdiri dari unsur-unsur mineral yang juga dikenal sebagai unsur anorganik atau kadar abu (Winarno, 2008). Gambar 2 menunjukkan kadar abu ikan biang asin kering berkisar antara 22,20 \% - 24,02 \%. Hasil ini hampir sama dengan penelitian Ali et al., (2014) kadar abu ikan asin di daerah Lampung sebesar 25,8\% dan penelitian Yusra (2017) kadar abu ikan talang sebesar 19,87\%. Kadar abu pada ikan bergantung pada habitat hidup ikan tersebut yang berhubungan dengan kandungan mineral yang terdapat pada tubuh ikan (Tsyaniyatul et al., 2013). Kadar abu juga dipengaruhi oleh suhu dan lamanya pengeringan. Riansyah et al., (2013) menyatakan semakin tinggi suhu dan lamanya waktu yang digunakan selama pengeringan maka akan semakin meningkatkan kadar abu dari ikan asin.

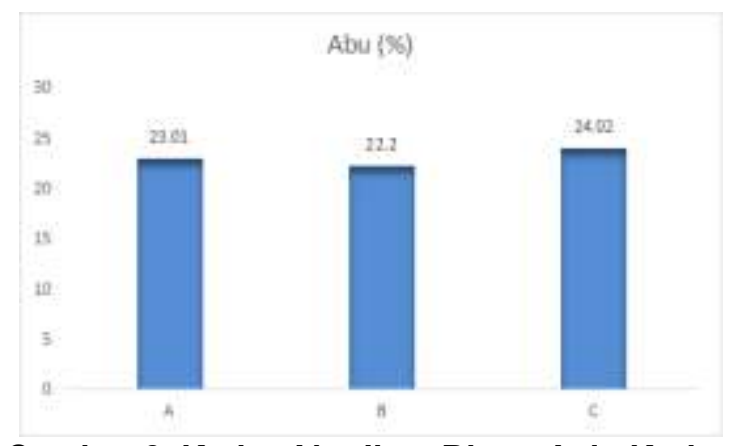

Gambar 2. Kadar Abu Ikan Biang Asin Kering 


\subsection{Kadar Protein}

Kadar protein ikan biang asin kering berkisar antara 46,68\% - 49,08\%. Nilai kadar protein yang beragam pada sampel dikarenakan adanya perbedaan konsentrasi garam. Rahmani et al., (2007) menjelaskan bahwa perbedaan konsentrasi garam berpengaruh terhadap struktur protein. Konsentrasi yang rendah menyebabkan protein mengalami salting in dan pada konsentrasi tinggi protein mengalami salting out. Pada proses salting in protein akan lebih mudah larut, sebaliknya pada peristiwa salting out protein akan mengendap dan tidak mudah larut. Pada proses salting in protein akan lebih mudah larut, sebaliknya pada peristiwa salting out protein akan mengendap dan tidak mudah larut. Kadar protein juga dipengaruhi lamanya pengeringan. Penelitian Riansyah et al.,(2013) menyatakan semakin tinggi suhu dan lama waktu pengeringan akan meningkatkan pada kadar protein pada ikan asin sepat siam. Peningkatan kadar protein ini karena adanya penurunan dari nilai kadar air seiring dengan semakin tinggi suhu dan lama waktu yang digunakan selama proses pengeringan.

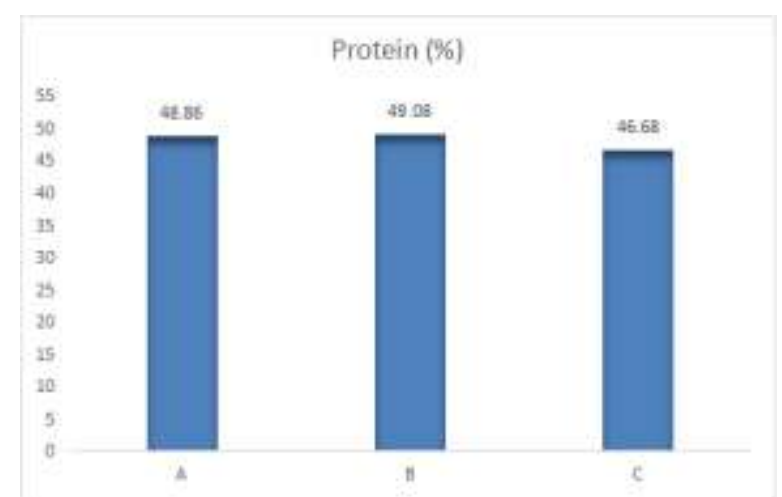

\section{Gambar 3. Kadar Protein Ikan Biang Asin Kering}

\subsection{Kadar Lemak}

Lemak adalah bahan-bahan yang dapat larut dalam eter, kloroform (benzene) dan tidak dapat larut dalam air. Lemak merupakan cadangan makanan dalam tubuh, karena kelebihan karbohidrat diubah menjadi lemak dan disimpan dalam jaringan adiposa (Winarno, 2008). Gambar 4. menunjukkan bahwa kadar lemak ikan biang asin kering berkisar antara 4,52\% - 5,77\%. Semakin tinggi konsentrasi garam semakin rendah kadar lemak ikan biang asin kering. Paparang et al., (2013) menyatakan peburunan kadar lemak yang disebabkan oleh pengaruh konsentrasi garam terjadi karena garam berperan sebagai katalis pada proses oksidasi lemak ikan.

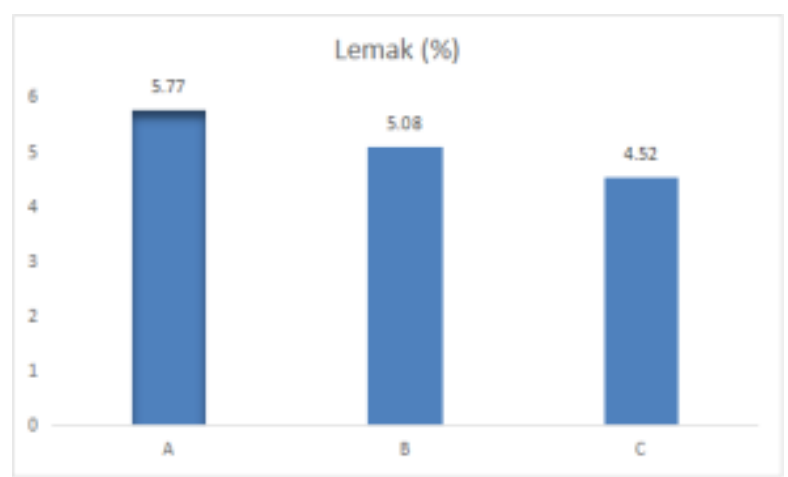

\section{Gambar 4. Kadar Lemak Ikan Biang Asin Kering}

\subsection{Kadar Karbohidrat}

Analisis kadar karbohidrat dalam penelitian ini menggunakan perhitungan by difference yaitu kadar karbohidrat dihitung menggunakan nilai sisa perhitungan akhir terhadap kandungan air, protein, lemak dan abu. Gambar 5. menunjukkan bahwa kadar karbohidrat ikan biang asin kering berkisar 
antara 6,07\% - 9,55\%. Kadar karbohidrat ikan biang asin kering dipengaruhi oleh besarnya proporsi kadar air, kadar abu, kadar protein, dan kadar lemak ikan biang asin kering ini. Karbohidrat pada hewan terdapat dalam bentuk glikogen. Glikogen banyak terdapat pada hati dan otot. Glikogen terdapat pada otot-otot hewan, manusia dan ikan. Glikogen juga disimpan dalam hati hewan sebagai cadangan energi yang sewaktu-waktu dapat diubah menjadi glukosa (Winarno, 2008)

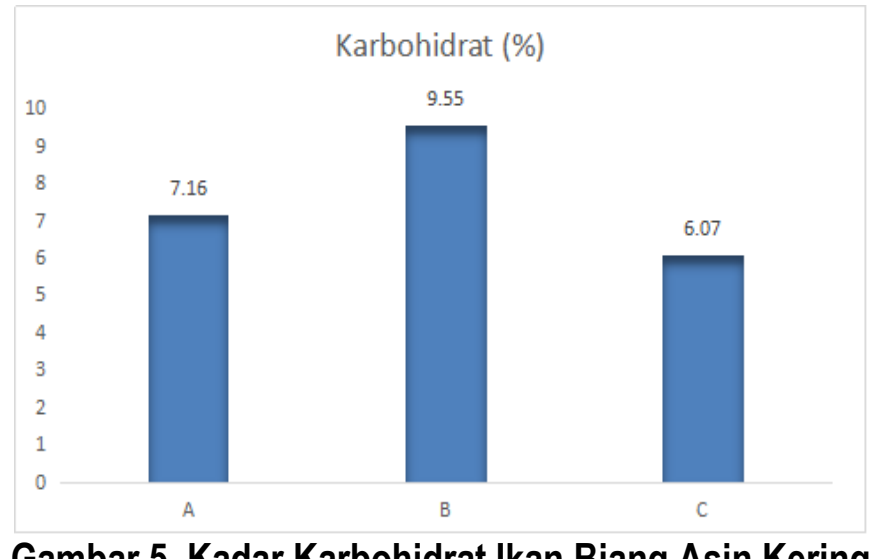

\section{Simpulan}

Berdasarkan hasil penelitian yang telah dilakukan, dapat disimpulkan bahwa perbedaan konsentrasi garam berpengaruh terhadap komposisi proksimat ikan biang asin kering. Kadar air, abu, protein, lemak, dan karbohidrat ikan biang asin kering secara berturut-turut berkisar 14,09\%-18,71\%; $22,2 \%-24,02 \% ; 46,68 \%-49,08 \% ; 4,52 \%-5,77 \%$; dan 6,07\%-9,55\%.

\section{Daftar Pustaka}

[AOAC] Association of Official Analytical Chemist. (2005). Official Method of Analysis of The Association of Official Analytical of Chemist. Arlington: The Association of Official Analytical Chemist, Inc.

Ali, M., Suparmono, \& S. Hudaidah. (2014). Evaluasi Kandungan Formalin pada Ikan Asin di Lampung. Aquasains, Jurnal IImu Perikanan dan Sumberdaya Perairan, 2 (2), 139-144.

[BPS] Badan Pusat Statistik. (2015). Produksi Nilai Perikanan Laut menurut Jenis 2014-2015. https://riau.bps.go.id

[BSN] Badan Standarisasi Nasional. (2009). Ikan Asin Kering. SNI 01-2721-2009. Jakarta.

Medina-Vivanco, M., Sobral, P.J.do A., \& Hubinger, M.D. (2002). Osmotic dehydration of tilapia fillets in limited volume of ternary solutions. Chemical Engineering, 86, $199-205$.

Ningrum R, Lahming, Mustarin A. (2019). Pengaruh Konsentrasi dan lama waktu penggaraman terhadap mutu ikan terbang (Hirundichthys oxchepalusi) asin kering. Jurnal Pendidikan Teknologi Pertanian, 5 (2), 26-35.

Novikov, N.P., A.S. Sokolovsky, T.G. Sokolovskaya \& Y.M. Yakovlev. (2002). The fishes of Primorye. Vladivostok, Far Eastern State Tech. Fish. Univ., 552 p.

Paparang RW. (2013). Studi Pengaruh Variasi Konsentrasi Garam terhadap Citarasa pada Ikan Layang (Decapterus ruselli). Jurnal Media Teknologi Hasil Perikanan. 1 (1), 17-20.

Rahmadi., Yunianta \& E. Martati. (2007). Pengaruh Metode Penggaraman Basah terhadap Karakteristik Produk Ikan Asin Gabus (Ophiocephalus striatus). Jurnal Teknologi Pertanian. 8 (3), 142- 152. 
Riansyah A, Supriadi A, \& Nopianti R. (2013). Pengaruh Perbedaan Suhu dan Waktu terhadap Karakteristik Ikan Asin Sepat Siam (Trichogaster pectoralis) dengan menggunakan oven. Fistech, 2 (1), 53-68.

Tsaniyatul SMS, Dwi TS, \& Suprayitno E. (2013). Pengaruh Suhu Pengukuran terhadap Kandungan Gizi dan Organoleptik Abon Ikan Gabus (Ophiocephalus striatus). THPi Student Journal, I (1), 33-45.

Tuyu A, Onibala H, \& Makapedua DM. (2014). Studi Lama Pengeringan Ikan Selar (Selaroide sp) Asin dihubungkan dengan Kadar Air dan Nilai Organoleptik. Jurnal Media Teknologi Hasil Perikanan. 2 (2):1-7.

Winarno FG. (2008). Kimia Pangan dan Gizi. Jakarta: PT. Gramedia Pustaka Utama.

Zhang J. \& T. Takita. (2007). Age and Growth of Ilisha elongata (Teleostei: Pristigasteridae) in Ariake Sound, Japan: comparison among population in western North Pacifik Ocean. Japanese Society of Fisheries Science. Fisheries Science. 73, 971- 978. 